\title{
Universities in the United States of America.
}

[NFORMATION about higher education and research in the United States is available in great, to the uninitiated, indeed, in embarrassing abundance. Besides the 'catalogs' and reports of a thousand colleges, universities, and professional schools, there are the excellent statistical summaries and surveys of the Bureau of Education, a plentiful stream of articles in American periodicals, reports of investigations carried out under the direction of great educational associations and foundations such as the Carnegie Foundation for the Advancement of Teaching, and records of impressions of visitors from Europe. 'The conceptions current in Great Britain owe their origin largely to the last-mentioned source and, perhaps not less, to unpublished impressions of other visitors to America, to contact with American visitors to Europe, including Rhodes scholars, and to references in popular fiction. Anyone desiring to apply to conceptions thus formed the test of a purely objective, well-authenticated, comprehensive, and up-to-date survey could not do better than study the handbook ${ }^{1}$ recently issued by the American Council on Education.

This volume gives, first, an admirably lucid account of the organisation of elucation in the United States and the character and relations of college, university, professional school, and graduate school of arts and sciences, and, secondly, particulars indicating the general character and resources of each of the 398 universities and colleges accredited by the five great standardising bodies ${ }^{2}$ which, in the absence of a central governmental authority, provide for the development of co-operation among these institutions and between them and the schools. These bodies have all adopted and applied standards formulated by the American Couneil on Education which was constituted by the leading educational associations and universities and colleges in 1918.

The American ' college' stands between the British secondary school and university, offering a general education during four years and conferring a bachelor's degree. Its first two years are comparable with the last two of a European lycée or gymnasium, and its last two with the first two of the French or German university. The 'university' comprises " a college or colleges of Arts, Literature, and Science-historically the first part of the American university to come into existence-and professional colleges or schools of Law, Medicine, Theology, etc., and, especially, a graduate school of Arts, Literature, and Science.'

For admission to one of the 'accredited' lists, a college has to fulfil a number of minimum requirements, among which are: an adequate staff (for example, for a college of 100 students, in a single curriculum at least eight full-time heads of departments); a moderate 'teaching load,' normally not more than 16 hours a week for an instructor or classes (exclusive of lectures) of more than 30 students ; annual operating income, exclusive of payment of interest, annuities, etc., of at least 50,000 dollars, of which not less than 25,000 dollars should be derived from stable sources, other than students, preferably from permanent endowments; a library of at least 8000 volumes, exclusive of public documents. No college is accredited until it has been inspected and

1 “American Universities and Colleges." Edited by David Alan Robertson. Pp. xii +884 . (New York and London: Charles Scribner's Sons, 1928.) $12 s$. $6 d$. net.

2 Association of American Universities, North Central Association of Colleges and Secondary Schools, Association of Colleges and Secondary Schools of the Southern States, Association of Colleges and Secondary Schools of the Middle States and Maryland, and the North-West Association of Secondary and Higher Schools. reported upon by agents regularly appointed by the accrediting organisation.

Co-education prevails in the west; separate colleges for women exist particularly in New England and the Atlantic States, north and south. The organisation and influence of men and women who have been students together are extraordinarily effective in America. Their secretaries have become so numerous and energetic that since 1913 they have had their own association, which has published, in addition to reports of their conferences, a "Manual of Alumni Work." A statistical study of campaigns conducted recently by sixty-eight institutions for raising funds shows that of a total sum of 150 million dollars, nearly half was obtained from alumni. Their influence has been felt not only in financial campaigns but also in matters of educational policy, and they show an increasing willingness to co-operate with employment bureaux and appointment offices.

The resources of higher education in America have expanded rapidly since the War. The latest statistics of the Bureau of Education show that between 1920 and 1926 the total annual receipts of colleges, universities, and professional schools (numbering 975 in 1926) increased from 240 to 480 million dollars, the money value of their buildings and equipment in almost equal proportion, and the number of professors and instructors from 42,882 to 62,224 . So great, however, has been the simultaneous expansion of the demand for admission to these institutions that their resources have been overtaxed and they have been driven to adopt protective measures a yainst the danger of being swamped by excessive num Jers. They have imposed new and stricter conditions of admission, designed to ensure the selection of those best qualified to carry their studies to a successful issue, and there has been much discussion of fundamental questions as to the aims and purposes of higher education and what are the types of student best fitted, from the point of view of the interests of the community, for admission to its benefits.

The overcrowding with which the colleges have been afflicted has not been without compensating benefits. Whereas formerly colleges competed injuriously one with another for students, and there was excessive emphasis on externals-buildings and equipment - they are now in a position to insist on higher standards of qualification for admission, and emphasise quality rather than mere numbers. In some States the State university is required to accept any applicant for admission who has obtained a leaving certificate from the principal of any accredited high school. In more cases, however, the college requires the completion of specified work in English (3 units), foreign language (3), mathematies (2), history (1), science (1), and many admit only those students who ranked in the first seventh or first quarter of their class at the close of their school course.

Nor is this new emphasis on the quality of the student confined to the testing of his fitness for admission. The responsibility of the college for developing the individual student is increasingly recognised, and elaborate records are prepared both at entrance and afterwards for use by professors and future employers. In 1927 the American Council on Education received a grant of 20,000 dollars a year for the development of "personnel procedure"-a term signifying the various efforts by which it is sought to bring the college into closer individual touch with its students. Many of these efforts are directed

No. 3071, Vou. 122] 
towards placing the student in some appropriate employment. "With the development of personnel procedure," says Dr. Robertson, "including greater attention to the analysis of individual abilities and achievements, there has come a desire to have useful occupational information. . . . When the world's work has been analysed and the skills and qualities required for particular jobs have been specified, the schools and colleges can shape their curricula and methods of instruction to attain more quickly and effectively the objectives of education as they pertain to vocations." This passage is significant of the trend of much of recent American research in the field of higher education. Attention is focused more on brains and service, and less on bricks and mortar.

\section{Meristematic Tissues of Plants.}

$I^{\mathrm{T}}$ should be unnecessary to emphasise the importance of focusing attention on plant meristems, and yet the subject is one which is either sadly neglected or receives but scant attention. Botanists with a progressive or inquisitive turn of mind will therefore read with interest Prof. J. H. Priestley's paper on plant meristems (Biological Reviews, vol. 3, No. 1).

Different types of meristem are passed in review from a 'causal' viewpoint, and an attempt is made to show that each stage in development depends on preceding events, and releases in turn a system of internal correlating factors which control the progress of growth. The author draws a sharp distinction between shoot meristems, which are superficial, and root meristems, which are deep-seated, and gives some tentative reasons why their continued developments are markedly different. Repeated microchemical tests have confirmed his conclusion that the walls of the root meristem cells are in a more undifferentiated state than those of the shoot, being still impregnated with fatty and protein materials.

Now, postulating the passage of nutrient substances along differentiated cellulose walls, Prof. Priestley considers that most of the divisions in root meristems are internal because food material has some difficulty in passing to the outermost layers of cells. At the same time, divisions occur for the most part in a plane transverse to the root axis, giving the Rippenmeri- stem of Schüepp. Both of these factors are used to explain why the root grows mostly in length. In the shoot meristem, on the other hand, sap passes readily along the more differentiated cell walls, with a resulting greater division of cells in the superficial layers. Thus the primordia of bud-scales, leaves, and flowers are laid down. The repeated tangential divisions of cambium cells, contrary to Errera's Law, are explained by the fact that cambium cells are never in equilibrium with the surrounding cells, lying as they normally do across a hydrogen ion gradient between phloem and xylem.

Some interesting suggestions are put forward regarding the position of the cambium elements formed just behind the root tip. In a former paper by Dr. Pearsall and Prof. Priestley, it was shown that the reaction of cambium (in terms of hydrogen ion concentration) is intermediate butween the relatively alkaline phloem and the relatively acid xylem. This reaction is approximately the reaction at which most plant proteins are isoelectric, and in the vicinity of which most protoplasmic synthesis takes place. In the young root, the protophloem groups and the protoxylem groups, on alternate radii, exude their saps respectively alkaline and acid, and in the regions where these saps intermingle, the hydrogen ion concentration necessary for the formation of cambium obtains.

\section{Orientalists at Oxford.}

$\mathrm{N}^{\mathrm{or}}$ OT only was the Seventeenth International Congress of Orientalists, which was held at Oxford on Aug. 27-Sept. 1, the first meeting of that body since the War, but it was also the largest gathering that had ever taken place. It is an encouraging sign of the position of orientalists' studies at the moment that, in addition to the ordinary members, there were present two hundred official delegates, who represented the principal governments and universities of the world. Notwithstanding the fact that the meeting took place in mid-vacation, Oxford provided ample entertainment for her guests in the form of garden parties, etc. An official luncheon was given by the British Government in the hall of Christ Church on the opening day, at which Sir William Marris, member of the Council of India, presided. In welcoming the delegates he paid an eloquent tribute to the work of Sir George Grierson in the Linguistic Survey of India. A banquet was held on the evening of Aug. 31.

The Congress met in eight sections, each with its own chairman, Lord Chalmers presiding over the whole. The sections with their presidents were as follows: (1) General, Prof. J. L. Myres; (2) Assyriology, Prof. S. P. Langdon; (3) Egypt, Prof. F. Ll. Griffith ; (4) Central and Northern Asia, Prof. F. W. Thomas; (5) the Far East, Prof. W. E. Soothill;
(6) (a) : 1. Ancient India, 2. Modern India; (b) Iran, Armenia, and the Caucasus, Prof. F. W. Thomas; (7) Hebrew and Aramaic, Prof. G. A. Cooke; (8) Islam and Turkey, Prof. D. S. Margoliouth; (9) Oriental Art, Sir Michael Sadler.

The proceedings covered a wide range, as may be gathered from the fact that one paper even dealt with the languages of Australia. Perhaps Assyriology held pride of place in attracting attention, and justified the title applied to it by Prof. Langdon when he called it the "Queen of modern Historical Research." In his survey of recent developments in the subject, he emphasised the value of the German discoveries in Hittite Boghaz Keui, the extension of our knowledge of Sumerian, the recovery of the lists of early dynasties at Ur, and the "astonishing" discoveries in the Indus Valley. Mr. Woolley's account of his excavations at Ur and the evidence for human funerary sacrifice aroused much interest; but perhaps the most appropriate of all the items in the programme was the opening of this section on the first full day of the proceedings of the Congress with a paper by the veteran scholar, the Rev. A. H. Sayce, now in his eighty-third year.

It was significant of the breadth of interest of the Congress as a whole that the chair in the Section of Oriental Art was taken by Sir Michael Sadler, Master

No. 3071, VoL. 122] 